\title{
Opinions of high school students in central Elazig about elderliness
}

This article was published in the following Dove Press journal:

Clinical Interventions in Aging

29 April 2015

Number of times this article has been viewed

\section{A Ferdane Oguzoncul' \\ Murat Aygen ${ }^{2}$ \\ Yasemin Acik' \\ S Erhan Deveci' \\ B Canan Demirbag ${ }^{3}$ \\ Edibe Pirincci'}

'Department of Public Health, Faculty of Medicine, Firat University, Elazig, Turkey; ${ }^{2}$ Faculty of Economics and Administrative Sciences, Firat University, Elazig, Turkey; ${ }^{3}$ Department of Public Health, School of Nursing, Faculty of Health Sciences, Karadeniz Technical University, Trabzon, Turkey

Correspondence: A Ferdane Oguzoncul Firat Universitesi Tip Fakultesi, Halk Sagligi Anabilim Dali, Kat:3 23119 Elazig, Turkey Tel +90 04242370000 ext 4685 Email aferdane@gmail.com
Methods: Students attending five different types of high schools in central Elazig (a city in Turkey) during the 2009-2010 school year constitute the study population. One class was randomly selected from each high school. Out of 650 students, 640 participated in the study. The data were evaluated by using the SPSS program; percentage, mean, and chi-square analyses were used.

Findings: Of all the students, $41.7 \%$ defined the elderly as those who are 60 years of age or older. When asked the question "What does elderliness mean to you?", the majority of the students, $27.2 \%$, responded "peace and resting". The second most common answer, given by $23.6 \%$ of students, was "sickness/tiredness"; 16.6\% responded "wisdom/experience". Many students $(30.3 \%)$ stated that the most difficult thing about living with the elderly was their interference in everything; $30.6 \%$ of students stated that there was no difficulty at all. According to $42.7 \%$ of the students, the greatest problem that the elderly face is health. Of all of the students, $58.3 \%$ stated that they feared growing old.

Conclusion: Our study has concluded the following: 1) High school students have a conventional perception of elderliness and 2) They embrace the elderly and think that perspectives on elderliness will change through education.

Keywords: old age, elderly, high school students, opinion

\section{Introduction}

For every living creature, elderliness is the final and inevitable phase of life. ${ }^{1}$ Elderliness is an unstoppable phenomenon that has biological, chronological, and social aspects. The process is not the same for all; it exhibits differences based on the individual involved. ${ }^{2}$

The elderly population is on the rise worldwide both in terms of number and position in society. ${ }^{3}$ Although the extent of the increase varies with region and age group, the members of today's elderly population mostly reside in developed countries. However, a more rapid increase in the elderly populations of developing countries is expected in the future. ${ }^{4}$

It is foreseen that in many countries that are categorized as developing, the population of people ages 60 years or above will reach 1.2 billion in 2025 and two billion in the year 2050. ${ }^{5}$ While there is no particular range that demarcates the advent of elderliness, the most frequently used age limit is 65 years. $^{2}$ In terms demography and law, the concept of elderliness is used to denote those ages 65 years and older. ${ }^{3}$

Today, Japan is the nation with the oldest population. Life expectancy at birth in Japan is calculated to be 80 years. Life expectancy at birth is 79 years in countries such as Canada, Sweden, and Switzerland, whereas it is 78 years in countries such as England, France, the Netherlands, and Italy. Life expectancy at birth is 75 years or older in 37 world nations. $^{6}$ 
Parallel to these developments around the world, there has been an increase in the elderly population of Turkey as well. In the last second half of the 20th century (1950-2000) in Turkey, the percentage of the population that is 60 years of age or older has increased from $3.5 \%$ to $5.5 \%$ of the total population. This rate is increasing incrementally every day. ${ }^{6}$

Currently, there are approximately four million elderly people in Turkey. It is estimated that this number will double in the next 20 years, rising to seven to eight million, and then reach 12 million by the year $2050 .^{6}$

Since ancient times, mankind has sought and continues to seek answers to questions such as these: "Who is elderly?"; "Is there a beginning of elderliness?"; "When does someone feel old?"; and "Do the symptoms of elderliness present in the same way for every individual?" The famous historian Homer emphasizes the experience and wisdom of the elderly when he claims that the youth are ready to harness the ability and experience of the elderly. ${ }^{1}$ For Plato (427-347 BC), who draws attention to the individualistic aspect of the period of old age, the lifestyle during adolescence and adulthood is the determining factor in the activity and situation of an elderly individual. ${ }^{1}$

In different societies, various beliefs concerning the social meaning of aging and attitudes are held, and various customs toward the elderly are observed. In traditional societies, elderly people are seen as "guardians of culture" because of their experience and accumulated manners. Thus, they are perceived as individuals who bear significant social roles in the growth of the second generation and the preservation of culture. In modern societies, they are considered to be individuals whose productivity has come to an end, who are burdens for their families, and who are expected to die as soon as possible. ${ }^{7}$

People have also different perspectives about aging. There are significant variations in perspectives among different age groups and among different sociocultural and economic structures. The phenomenon of elderliness, which has been present since the beginning of humanity, has been increasing in importance in recent years. ${ }^{8}$ In societies in which industry is dominant, people are moving toward nuclear families, and the average lifespan is increasing. Consequently, the number of elderly people whose needs for accommodation and social support are met in care and nursing homes is increasing. ${ }^{6}$

In European countries such as Belgium, Denmark, France, and England, single individuals who are 65 years or older make up $11 \%$ of households. This rate is significantly lower in developing countries, where elderly people live with their children or their grandchildren. ${ }^{6}$ In Eastern societies (Thailand, the Philippines, Singapore, and Taiwan) most elderly people live with their children. ${ }^{9}$ Despite everything, Japan sustains a strong tradition of respect for social life and for parents as well as its tradition of integrating the elderly into social life. ${ }^{10}$ In Iran, also an Asian country, the elderly have started to live alone, particularly in urban areas, because of geographical and social mobility, an increase in the number of nuclear families, a decrease in the number of children, and women's integration into the workforce. However, only a quarter-century earlier, families, particularly those of the lower, lower-middle, rural, and even the upper-middle classes, used to live with their one or two sons. Elevations in social, cultural, religious, and economic situations; an increase in the standards of education and living; and modernization have resulted in radical changes in the family structure. This situation has left the elderly alone. ${ }^{11}$ This process began in the 1950 s in Turkey. Society is aging at a steadily increasing rate despite a high birthrate (population aged $65+$ years: $7.3 \%$ ). ${ }^{12}$

Throughout history, respect has been a milestone of our culture. Since time immemorial, ancestors have been respected and the elderly protected. Nevertheless, perspectives on old age vary, and elderliness is a complicated phenomenon. While some perceive elderliness as a problem, others adopt positive attitudes toward it. ${ }^{8}$

In our country, as in other countries undergoing the aging process, there exists a necessity to reconsider the phenomenon and policies surrounding elderliness. The conception of aging involves the discussion of subjects such as social integration of the elderly beyond mere daily care, the acquisition of lost statuses and roles, increasing functionality, and the efficient use of spare time. ${ }^{9}$

Elderliness elevates the status of an individual in almost every society. Senior citizens are individuals who are respected and enjoy some special privileges. In fact, this respect does not stem from age alone; wisdom, experience, and knowledge transmitted from ancestors, all of which are believed to come with age, increase the status of the elderly. ${ }^{13}$

The youth must get to know and understand adults and the elderly as much as adults need to know and understand the youth. In many conventional understandings, parents perceive caring for children as a social responsibility, and children believe that they must take care of their old parents. This attitude can also be seen in our traditions. ${ }^{13}$

The basic connection that the elderly have is to their families and particularly to their children. Therefore, it seems that the most significant source of social support is the nuclear family. ${ }^{14}$ Our society needs the elderly population as a balancing element and a source of experience. ${ }^{15}$

\section{Aim and objectives}

People have different perspectives concerning aging. There are differences in perspective among various age groups and 
among different sociocultural and economic structures. These differences reveal the relationships between the young generation and older generations (the pediatrics-geriatrics relationship), which may cause problems such as generational conflicts. In such situations, both groups may despise each other. The youth must get to know and understand adults and the elderly as much as adults need to know and understand the youth.

The aim of this study is to evaluate the perspectives on elderliness of students attending different types of high schools in central Elazig.

\section{Materials and methods}

Students attending five different types of high schools (private high schools, state high schools, science high schools, Anatolian high schools, and vocational schools of health) located in central Elazig during the 2009-2010 school year constitute the population of this study. One class was randomly selected from the first, second, third, and fourth grades of each participating high school. Out of 650 students, $640(98.4 \%)$ participated in the study.

Before conducting this study, written research permission was obtained from the Elazig Provincial Directorate of National Education, and participants provided their oral consent. A questionnaire in line with the relevant literature was developed by researchers and was administered to students under direct observation in order to collect data about their demographic features and opinions about elderliness. Regarding the questions on elderliness, the question of what the youth know about the elderly was taken into consideration. Open-ended questions were used as well as multiple choice questions so that those completing the surveys could best express their thoughts. The questions were mostly focused on the idea of the elderly and the imminent thoughts of students toward the elderly rather than direct examples of experiences with the elderly.

Data gathered from this study were evaluated by using the SPSS statistics program, and a chi-square test was used to detect significant frequency distributions, medians, standard deviations, and differences between groups. $P<0.05$ was considered statistically significant.

\section{Study limitations}

The study faced some limitations because conducting the study with all of the high school students in the city would be difficult in terms of time and cost. Because of this, only five different types of high schools in the city center (excluding districts and villages) were included in the study. For the study sample, one class was selected for each grade. The study was conducted with those students who agreed to participate. No exclusion criteria were defined for study participants.

\section{Results}

The age distribution of participating students was $16.51 \pm$ 1.11 years (minimum 14 years, maximum 20 years). The students' sociodemographic characteristics are seen in Table 1 .

Of all of the students, $41.7 \%$ defined the elderly as those who are 60 years of age or older. The mean of the age at which a person was considered elderly by the students was $53.90 \pm 9.392$ years. The students' opinions about elderliness are given in Table 2.

For the question, "Where should the elderly generally stay?", the answer distribution according to high school type is provided in Table 3 .

The percentage of those students who would want their parents to live with them was found to be $84.7 \%$ in private schools, $90.8 \%$ in vocational schools of health, and $93.8 \%$ in other types of high schools (state high schools, science high schools, Anatolian high schools).

\section{Discussion}

In the study, $41.7 \%$ of the participating students defined elderliness as being age 60 years or older. Students were asked at which age they thought elderliness began; the mean response was $53.90 \pm 9.392$ years. This is the average for the responses, for which the range was 30-85 years.

Table I Demographic characteristics of the 640 students who participated in the study

\begin{tabular}{lll}
\hline & N & \% of total N \\
\hline Gender & & \\
Male & 244 & 38.1 \\
Female & 396 & 61.9 \\
Family type & & \\
Nuclear & $54 \mathrm{I}$ & 85.6 \\
Extended & $8 \mathrm{I}$ & 12.7 \\
Separated & $\mathrm{II}$ & 1.7 \\
Home status & & \\
Owned by family & 436 & 68.1 \\
Rented & $13 \mathrm{I}$ & 20.5 \\
Public housing & 43 & 6.7 \\
Owned by family elder(s) & 30 & 4.7 \\
Paternal education & & \\
Illiterate & 29 & 4.5 \\
Literate & 40 & 6.3 \\
Primary school & 171 & 26.7 \\
Middle/high school & $24 \mathrm{I}$ & 37.7 \\
College/university & 159 & 24.87 \\
Maternal education & & \\
Illiterate & 129 & 20.2 \\
Literate & $7 \mathrm{I}$ & 11.1 \\
Primary school & 232 & 36.3 \\
Middle/high school & 147 & 23.0 \\
College/university & $6 \mathrm{I}$ & 9.5 \\
\hline No:The tot & &
\end{tabular}

Note: The total $N$ is 640.

Abbreviation: $\mathrm{N}$, number of students. 
Table 2 The 640 students' opinions on elderliness

\begin{tabular}{|c|c|c|}
\hline & $\mathbf{N}$ & $\%$ of total $\mathbf{N}$ \\
\hline \multicolumn{3}{|c|}{ Elderly group according to students } \\
\hline Below 60 years of age & 373 & 58.3 \\
\hline 60 years of age or older & 267 & 41.7 \\
\hline \multicolumn{3}{|c|}{ What does elderliness mean? } \\
\hline End of everything & 67 & 10.5 \\
\hline Wisdom, experience & 106 & 16.6 \\
\hline Peace and resting & 174 & 27.2 \\
\hline Sickness & $15 \mid$ & 23.6 \\
\hline Lack of self-sufficiency & 47 & 7.3 \\
\hline Loneliness & 95 & 14.8 \\
\hline \multicolumn{3}{|c|}{ Difficulties of living with the elderly } \\
\hline Generational conflict & 99 & 15.5 \\
\hline Intervening in everything & 194 & 30.3 \\
\hline Lack of self-sufficiency & 69 & 10.8 \\
\hline Communication & 82 & 12.8 \\
\hline No difficulties & 196 & 30.6 \\
\hline \multicolumn{3}{|c|}{ The biggest problem the elderly face } \\
\hline Lack of self-sufficiency & 90 & 14.1 \\
\hline Loneliness, indifference & 186 & 29.1 \\
\hline Not being understood & 91 & 14.2 \\
\hline Health problems & 273 & 42.7 \\
\hline \multicolumn{3}{|c|}{ Are you afraid of growing old? } \\
\hline Yes & 267 & 41.7 \\
\hline No & 373 & 58.3 \\
\hline \multicolumn{3}{|c|}{ Does conception of elderliness } \\
\hline \multicolumn{3}{|c|}{ change through education? } \\
\hline Yes & 595 & 92.9 \\
\hline No & 45 & 7.1 \\
\hline
\end{tabular}

Note: The total $\mathrm{N}$ is 640 .

Abbreviation: N, number of students.

The categorization of elderliness varies with the culture of the country and with life expectancy at birth. In a study conducted in Manisa, a definition of elderliness similar to ours was found. ${ }^{6}$ Since the group participating in the study comprised adolescents, their definitions of elderliness may be extended to younger age groups.

The majority of students (27.2\%) stated that for them, elderliness means "peace/resting", but $23.6 \%$ of students expressed that elderliness means "sickness". Young people's association of elderliness with illness may be related to their observations of the elderly around them. The proportion of those who claimed that elderliness means "wisdom/ experience" was $16.6 \%$, whereas in the study conducted in Manisa, $35 \%$ of young people stated that elderliness means "the end of everything". The proportion who defined elderliness as "wisdom" was $12.5 \%{ }^{6}$ In almost every society, elderliness provides an elevated status for the individual. The senior citizen is an individual who is respected and has some special privileges. ${ }^{11}$ Nurses working in a nursing home in İzmir considered elderliness to be a difficult period during which constant care is needed for health and social problems. ${ }^{16}$ The reason for obtaining different results in our study may stem from interregional and sociocultural differences.

Students maintained that the most important difficulty with living with the elderly is intergenerational conflict $(30.3 \%)$, while an almost equal portion of the students (30.6\%) expressed that there are no difficulties at all from living with the elderly. For a questionnaire in which respondents were asked, "To what extent do elderly people have certain characteristics?", 34\% of those ages 25-34 years old stated that the elderly talk nonsense; $44 \%$ of respondents considered them to be lazy; and $61 \%$ of respondents maintained that elderly people are stubborn. ${ }^{17}$

The majority of students (83.4\%) stated that the elderly should stay with their families. Compared to those attending of other types of schools, more students in vocational schools of health held that the elderly should be in nursing homes $(P<0.05)$. This response may be due to their applied classes, in which they observe sicknesses of the elderly. One out of every ten elderly persons lives alone. ${ }^{18}$ Similarly, in research conducted by Bekaroğlu in Trabzon, $66.6 \%$ of the elderly living in homes stated that they lived with their children or with their children and spouse, and $21.6 \%$ said that they lived with their spouses. ${ }^{19}$ Also, $8 \%$ of respondents stated that they lived alone, and $4.6 \%$ stated that they lived with other relatives. ${ }^{19}$

The percentage of those who want their parents to live with them when their parents grow old was $84.7 \%$ in private schools, $90.8 \%$ in vocational schools of health, and $93.8 \%$ in other types of high schools. Subasi and Oztek conducted a

Table 3 According to high school type, the distribution of answers to the question "Where should the elderly stay?"

\begin{tabular}{|c|c|c|c|c|c|c|}
\hline \multirow[t]{3}{*}{ Type of school } & \multicolumn{6}{|c|}{ Response to "Where should the elderly live?" } \\
\hline & \multicolumn{2}{|c|}{ With their families } & \multicolumn{2}{|c|}{ Nursing homes } & \multicolumn{2}{|c|}{ Own homes } \\
\hline & $\overline{\mathbf{N}}$ & $\%$ & $\overline{\mathbf{N}}$ & $\%$ & $\overline{\mathbf{N}}$ & $\%$ \\
\hline Private high school & 106 & 88.3 & 3 & 2.5 & 11 & 9.2 \\
\hline Vocational schools of health & 97 & 82.9 & 8 & 6.8 & 12 & 10.3 \\
\hline Other* & 331 & 82.2 & 9 & 2.2 & 63 & 15.6 \\
\hline Total** & 534 & 83.4 & 20 & 3.2 & 86 & 13.4 \\
\hline
\end{tabular}

Notes: *Other: state high schools, science high schools, Anatolian high school. **Percentages are with respect to the total of the line $(534) . \chi^{2}=10.722 ;$ standard deviation $=4$; $P=0.03$ (statistically significant at $P<0.05$ ).

Abbreviation: $\mathrm{N}$, number of students. 
study of 1,055 households in Ankara's Cankaya district to investigate the opinions of people over 18 about elderly care. ${ }^{20}$ In the study, $75.0 \%$ of participants stated that children should take care of their parents who are old and cannot look after themselves. They maintained that elderly individuals should be cared for in their own homes. ${ }^{20}$ In a study conducted by Baran et al in 2005 to analyze the relationship between elderly people and their families, $69.5 \%$ of individuals who were providing care for the elderly (son, daughter-in-law, daughter, son-in-law, or grandchildren) think that the elderly should be looked after by the son and daughter-in-law or by the daughter and son-in-law. ${ }^{21}$ On the other hand, the percentage of those who think that the elderly should be taken care of privately for a certain amount of money (3.5\%) and the percentage of those who think that public institutions should provide care for the elderly $(5.5 \%)$ were quite low. Also, $93.8 \%$ of the elderly maintained that they were happy to be living with their children. ${ }^{21}$

\section{Conclusion}

Our study found that high school students generally perceive elderliness in a traditional manner, and they think that perspectives on elderliness may change through education. Necessary precautions to ease life and care for the elderly staying at home should be taken. Therefore, families should be supported and social support should be provided.

\section{Disclosure}

The authors report no conflicts of interest in this study.

\section{References}

1. Kaygusuz C, Kalkan M. [Counseling for the elderly.] Yaslilik Danismanligi. In: Ersanli K, Kalkan M, editors. [Elderliness in Rerms of Psychology, Society and the Body.] Psikolojik, Sosyal ve Bedensel Acidan Yaslilik. Ankara: Pegem Academy Publishing House; 2008. Turkish.

2. Ornek T, Bayraktar E, Ozmen E. [Geriatric Psychiatry.] Geriatrik Psikiyatri. Bornova: Saray; 1992. Turkish.

3. Rakicioglu N, Atilla S. [Nutrition in the Elderly.] Yaslilikta Beslenme. Technical Report. Association of Public Health Institution. 2003;8:7-8.

4. Population Division, Department of Economic and Social Affairs. World Population Ageing 1950-2050. New York: United Nations Publications; 2001. Available from: http://www.un.org/esa/population/publications/ worldageing 19502050/. Accessed April 27, 2010.

5. Turkish Republic Ministry of Health General Directorate of Basic Health Services 2002. Health of the Elderly (Yasli Sagligi): 1.

Clinical Interventions in Aging

\section{Publish your work in this journal}

Clinical Interventions in Aging is an international, peer-reviewed journal focusing on evidence-based reports on the value or lack thereof of treatments intended to prevent or delay the onset of maladaptive correlates of aging in human beings. This journal is indexed on PubMed Central, MedLine,
6. Demet MM, Taşkın O, Deniz F, Karaca N, İçelli İ. [Prevalence of depression symptoms in the elderly people residing in Manisa nursing homes and related risk factors.] Manisa huzurevlerinde kalan yaşlılarda depresyon belirtilerinin yaygınlı̆̆ 1 ve ilişkili risk etkenleri. Türk Psikiyatri Dergisi. 2002;13(4):290-299. Turkish.

7. Kacar G. [Life Adaptations, Tendencies, Attitudes and Behaviors of the Elderly People under Different Urban Conditions.] Yaslilarin Farkli Kentsel Kosullarda Yasam Uyumlari, Egilimleri, Tutum ve Davranislari. In: Sosyal Antropolojik Acidan Bir Degerlendirme [doctoral thesis]. Ankara: Ankara University; 2000.

8. Kalkan O. [Elderliness.] Yaslilik [webpage on Internet]. Available from: http://www.bsm.gov.tr/makale/20011.asp?sayi=2001. Accessed April 27, 2010.

9. Kim IK. Social support for older persons: The role of family, community and state in selected Asian countries. In: Expert Group Meeting on the Regional Preparation for the Global Review of Madrid Plan of Action on Aging; March 27-29, 2007; Bangkok, Thailand.

10. The Elderly in Modern Society: A Cultural Psychological Reading [webpage on Internet]. Pittsburgh: Janus Head; 2007. Available from: http:// www.janushead.org/JHSpg99/pope.cfm. Accessed April 27, 2010.

11. Hegland ME, Sarraf Z, Shahbazi M. Modernization and social change: The impact on Iranian elderly social networks and care systems. Anthropology of the Middle East. 2007;2(2):55-73.

12. The Health Statistics Almanac (Saglik istatistikleri yilligi). 2011. Available from: http://sbu.saglik.gov.tr/Ekutuphane/kitaplar/siy. Accessed April 27, 2010.

13. Expressive Attitude: The Cowardly Elderly People [webpage on Internet]. Available from: http:/7xycorps.blogspot.com/2005/08/ cowardly-elderly-people.htlm. Accessed July 10, 2006.

14. Jarvik LF, Small GW. Geriatric psychiatry: overview. In: Sadock BJ, Sadock VA, eds. Kaplan and Sadock's Comprehensive Textbook of Psychiatry. 7th ed. Philadelphia: Lippincott Williams and Wilkins; 2000:2980-2988.

15. Özer M, Karabulut ÖÖ. [Life satisfaction in the elderly.] Yaşlılarda yaşam doyumu. Geriatri. 2003;6(2):72-74.

16. [III National Psychiatry Nursing Congress.] III Ulusal Psikiyatri Hemsireligi Kongresi. June 4-6, 2009; Akcakoca: 125. Available from: http://www.phdernegi.org/kongre_dokumanlar/iii.uphk_ozet_kitabi. pdf. Accessed April 27, 2010.

17. TÜRKIYE'DE TOPLUMDA YAŞLI INSSANLARIN YERI [COMMUNITY IN THE ELDERLY PEOPLE 'S PLACE IN TURKEY]. Available from http://www.tuyev.org.tr/haberler/index.php?haber_id=6. Accessed April 27, 2010.

18. "Yaşlıların Dünyası" Araştırması [webpage on the Internet]. Turkey age of science and technology foundation; 2011 [updated May 1, 2011]. Available from http://www.tuyev.org.tr/haberler/index.php?haber_id=5. Accessed April 27, 2010. Turkish

19. Bekaroğlu, Mehmet. [The reality of nuclear family and elderliness.] Çekirdek Aile Gerçeği ve Yaşl111k. [Proceedings of the 1st Family Council.] Aile Şurası Bildirileri, Başbakanlık Aile Araştırma Kurumu Yayınları, Ankara: Prime Ministry Institution for Family Research Publications; 1990:279-284.

20. Subasi N, Oztek Z. Some Opinions of the Elderly Living in Cankaya on Elderly Care (Cankaya Ilcesinde Yasayan Yaslilarin Yasli Bakimi Konusundaki Bazi Dusunceleri). 2004. Available from: http://www. dicle.edu.tr/ halks/yedi\%205, html. Accessed April 2005.

21. Baran AG, Kalinkara V, Aral N. [Elderly and family relations: the case of Ankara.] Yaşlı ve Aile İlişkileri-Ankara Örneği. Ankara: TC Başbakanlık Aile ve Sosyal Araştırmalar Genel Müdürlü̆̈̈̈̈. 2005;(127).

\section{Dovepress}

CAS, Scopus and the Elsevier Bibliographic databases. The manuscript management system is completely online and includes a very quick and fair peer-review system, which is all easy to use. Visit http://www.dovepress. com/testimonials.php to read real quotes from published authors. 